\title{
Ownership and private property from the perspectives of Hegel and Marx
}

By: Desiree Hidalgo

\begin{abstract}
The concept of private property has been widely explored and debated among scholars, since different conceptions of freedom are directly involved. Different notions of freedom have also been analyzed from the perspective of key figures in the history of modern political thought such as those from Hegel and Marx. This essay explores the theme of private property, analyzing how freedom is important for both theorists, but at the same time how their approaches diverge. Through the analysis and examination of their texts this paper argues for the Marxist approach since it provides a solution to the problem of inequality in regards to freedom.
\end{abstract}

Ownership and private property have extensively been discussed in political theory since these topics directly involve our conception of the freedoms of the individual. Both Hegelian and Marxist theories have contributed significantly to this relation between private property and freedom, although their accounts differ drastically from each other. The difference relies on what each considers to be the specific role that private property plays in shaping and defining freedom. Hegel sees private property necessary for the self-consciousness of free will, whereas Marx sees it as an impediment to the dissolution of oppression of the majority. In the section entitled Abstract Right in Hegel's Outlines of the Philosophy of Right, he provides an interpretation of modern social institutions and how they bring freedom to citizens. Through the use of these institutions, freedom is a developmental process that makes a person self-conscious of their will. Conversely, Marx analyses private property in the context of the effects that it has on workers, namely the proletarians. He acknowledges different social classes, and how the minority bourgeoisie own the means of social production. This appropriation has in turn alienated the majority of people from the fulfillment of freedom. In this essay I will evaluate the contexts in which Hegel and Marx analyze private property, as well as their distinct understanding of what ownership is. I will argue that Marx's view of private property is more valid of an account than Hegel since the former attempts to address palpable problems that affect people in their development of freedom, whereas Hegel deals with the subject matter in a conceptual manner. To explain this, I will first take into account Hegel's view, and the development of ownership he provides, according to which consciousness of freedom increases progressively. Then I will contrast this view to the concept of contract. Later I will analyze Marx's view on private property and how he connects it to the oppression that it causes on laborers by alienating them in different ways. I will analyze the four phases of alienation he describes. Finally I will conclude with the different contexts in which both theorists have deal with the subject.

In his Outlines of the Philosophy of Right, section "Abstract Right", Hegel discusses the issue of freedom in the context of its manifestation in the external world. For Hegel, freedom is granted to individuals who by nature possess mind and will. It is by having these properties that man is free since he is able to command over his will, which is made actual when ownership is manifested. It is through the decisions of the agent that mind conceptualizes to the external world. Thus the exercise of freedom is the proof of the right of free will that humans posses. He sees social institutions are of secondary importance, the point is that each individual should work on his freedom. He claims that it is the modern world, which is permitting agents to be conscious

The Agora: Political Science Undergraduate Journal Vol. 3 No. 2 (2013) 
of their free will. Hegel suggests, "since my will, as the will of a person, and so as an individual will, becomes objective to me in property, property acquires the character of private property" ( $\S$ $46)^{1}$. While it might seem that Hegel's account of individuality is granting unrestricted acquisition of property he actually touches on limits of this freedom, given that the exercise of free will can have effect on other individuals, he says 'be a person and respect others as persons' $(\S 36)^{2}$. This is the given basis on which people can practice their rights. Nonetheless selfconsciousness of freedom is primordial for agents to exercise the development of ownership which allows to a more superior realization of freedom.

Hegel suggests that in order for a person to be conscious about his freedom, he needs to externalize it to the world in order for it to become an idea. Ideas for Hegel are conceptualizations that have taken form in the external world. According to Hegel, "A person must translate his freedom into an external sphere in order to exist as Idea" $(\S 41)^{3}$. The externalization of an idea means that a person by obtaining private property is demonstrating a degree of reasoning since he is commanding over an object. A person by having theories or concepts would not be able to externalize ideas, and this suggests that reason cannot be achieved by having concepts in the mind but it is necessary to make them ideas ${ }^{4}$. Private property would also make individuals be recognized as free agents by other people. In this way other agents would be able to see that a person owns something, and therefore this individual can be treated as a realized person ${ }^{5}$. The legitimate ownership makes an individual be seen as having a personality capable of externalizing ideas. The person is then regarded as a property owner who is able to decide on the ends of such property. By acquiring property an agent lets other people know that the object is of exclusive use to the owner; in turn the object becomes unattainable to others. The realized person in this sense needs to express ideas objectively, with recognition from others. Hegel's analysis provides three forms of development that enforce the agent as having a free will in society ${ }^{6}$. After he discusses freedom in "Abstract Right", he evaluates sections on Morality and Ethical Life. However it is only after he has analyzed freedom that he moves on to elaborate on Morality and later on Ethical life. In this sense one can grasp the importance of the realization as a person in order to move further into the balance of an agent's life between morality and ethical life. This suggests the importance of the conceptualization of an agent's freedom to external things. Accordingly, Hegel says that people can begin to realize their freedom by taking things for their private property. Since objects do not have mind, and therefore not freedom they are of use to people through the right of appropriation. He says, "A person has as his substantial end the right of putting his will into any and every thing and thereby making it his, because it has no such end in itself and derives its determination and soul from his will. This is the absolute right of appropriation which humans beings have over all 'things"” (Hegel $\S 44)^{7}$. In this way Hegel

${ }^{1}$ G.F.W Hegel, Outlines of the Philosophy of Right. Trans. T. M. Knox. Ed. Stephen Houlgate. (New York: Oxford University Press, 2008), 61-62

2 Ibid. , 55

${ }^{3}$ Ibid. , $57-58$

${ }^{4}$ Dudley Knowles, Routledge Philosophy Guidebook to Hegel and the Philosophy of Right. (New York: Routledge, 2002), 107-108

${ }^{5}$ Ibid. , 116-117

${ }^{6}$ Ibid. , 113-114

${ }^{7}$ G.F.W Hegel, Outlines of the Philosophy of Right. Trans. T. M. Knox. Ed. Stephen Houlgate. (New York: Oxford University Press, 2008), 60

The Agora: Political Science Undergraduate Journal Vol. 3 No. 2 (2013) 
acknowledges that agents just for being persons are granted with the right to appropriate objects. The union of the free will with an object gives a new meaning to the understanding of freedom. Humans represent their personal differences through ideas, and they take form through private property. Private property in this sense is of importance to demonstrate the individuality of people. Agents acquire individuality and differentiation to the eyes of others ${ }^{8}$. According to Hegel there is a development to the achievement of appropriation and the making of an object into private property. He claims that taking possession, use, and alienation when analyzed expose how an agent can acknowledge his will to a higher stage of consciousness ${ }^{9}$. The first stage is when an agent takes possession of an unowned thing, he acknowledges his personality over other people who might have considered taking it. According to Hegel, "We take possession of a thing by directly grasping it physically, by forming it, and by merely marking it ours" $(\S 54)^{10}$. Thus by physically making a contact with an object the will becomes visibly present, the thing would then be subjected to the person by ultimately representing his property. This progression culminates in the idea, which is the externalization of the agent's free will. The second stage of the relationship between a thing and the will is the use of the object after it has been taken as property. This stage is in turn is connected to the desires and preferences of people, as Hegel says, "Yet my need, as the particular aspect of one will, is the positive element which finds satisfaction, and the thing, as something negative itself, exists only for my need and is at its service" $(\S 59)^{11}$. The acknowledgement of the thing as property is used to express will in it, as one could do as he pleases with the object. The last stage of the development of property is alienation. According to Hegel alienation demonstrates more than the other two stages, that one is a free agent with free will. This is an enforcement of the will because a person has the command over an object, "The reason I can alienate my property is that it is mine only insofar as I put my will into it" $(\S 65)^{12}$. This domination over property grants the agent with the possibility to get rid of his objects since they serve to his desires or needs. By getting rid of what in the begging made an agent conscious of his free will, only proves how his command over property has, in this sense, no limit. However Hegel claims that people cannot own persons since others are free agents and to command over them would be contradictory to the right all individuals have. A slave for instance would not be free since he is not commanding over something, but is rather told what to do. As he says, "Therefore those goods, or rather substantial characteristics, which constitute my very own person and the universal essence of my self-consciousness are inalienable and my right to them is imprescriptible" $(\S 66)^{13}$.

The right to appropriate and externalize free will with private property, according to Hegel leads to contract. It is important to remember that possession over something is not the

\footnotetext{
${ }^{8}$ Dudley Knowles, Routledge Philosophy Guidebook to Hegel and the Philosophy of Right. (New York: Routledge, 2002), 120-121

${ }^{9}$ Ibid. , 123

${ }^{10}$ G.F.W Hegel, Outlines of the Philosophy of Right. Trans. T. M. Knox. Ed. Stephen Houlgate. (New York: Oxford University Press, 2008), 67

11 Ibid. , 71-72

12 Ibid. , 77

${ }^{13}$ G.F.W Hegel, Outlines of the Philosophy of Right. Trans. T. M. Knox. Ed. Stephen Houlgate. (New York: Oxford University Press, 2008), 77-78
}

The Agora: Political Science Undergraduate Journal Vol. 3 No. 2 (2013) 
same thing as having private property. It is only through private property that an agent achieves consciousness of their free will. "The sphere of contract is made up of this mediation whereby I hold property not merely by means of a thing and my subject will, but by means of another person's will as well and so hold it in virtue of my participation in a common will" $(\S 71)^{14}$. The contract is intended to regulate the effects of alienation of other individuals. This discussion leads Hegel to consider punishment as a means to preserve the right of property. Punishment will enforce the right of an agent towards private property, since the violation of the free will leads to the negation of failing to recognize agent's rights. The basis of punishment is considering that alienation and appropriation of objects has influence on others, "It is the meditation of the will to give up a property, an individual property, and the will to take up another, i.e. another belonging to someone else; and this meditation takes place when the two wills are associated in an identity in the sense that one of them comes to its decision only in the presence of the other" (Hegel $\S$ $74)^{15}$. It is the sense of punishment that will later make Hegel consider Morality. However his account does not explicitly deal with a form of distribution in which every individual would be granted to a form of private property, whereas Marx looks at the issue of distribution with primordial importance.

Marx's writings in the Communist Manifesto evaluate the two social classes that have been the result of historical change. Marx asserts that the bourgeoisie are the modern capitalists who own the social means of production, and who are the employers of wage-laborers ${ }^{16}$. On the other hand the proletariat, which conform the majority of people, are the laborers that work for wages in order to survive ${ }^{17}$. "Communists" as Marx refers to the movement conformed by the proletarians, have gathered with the political goal of abolishing the capitalist regime; "The immediate aim of the Communists is the...formation of the proletariat into a class, overthrow of the bourgeoisie supremacy, conquest of political power by the proletariat" ${ }^{\text {"18. }}$. As it can be seen, private property is of main concern to Marx since it is causing alienation of the majority and the generation of capital for a minority, and thus these are two connected issues. Marx uses the term alienation to describe how laborers are neglected of the development of their human faculties by being reduced to sell their labor in order to survive, as he says that the laborer becomes a "cheaper commodity the more he produces"19. Marx says of capitalism that it has, "centralised means of production, and has concentrated property in a few hands" 20 . If for Hegel private property causes freedom, private property for Marx causes alienation to freedom of the proletariat. Laborers as a cause aim for the "abolition of private property" 21 . Marx analyzes four ways in which the proletariats are affected by the private property of the bourgeoisie. He suggests that communists are attempting to change the mode of production in the given circumstances that world events occur, and he criticizes Hegelians for doing the contrary, as he claims, "in no way are they attacking the actual existing world; they merely attack the phrases of this world"22. Marx

${ }^{14}$ Ibid. , 83-84

${ }^{15}$ Ibid. , 84-85

${ }^{16}$ Karl Marx, Selected Writings. Trans. and Ed. Lawrence Simon. (Indiana: Hackett Publishing Company, 1994), 158

${ }^{17}$ Ibid. , 159

18 Ibid. , 169

${ }^{19}$ Karl Marx, Selected Writings. Trans. and Ed. Lawrence Simon. (Indiana: Hackett Publishing Company, 1994), 59

${ }^{20}$ Ibid. , 163

${ }^{21}$ Ibid. , 170

${ }^{22}$ Ibid. , 106

The Agora: Political Science Undergraduate Journal Vol. 3 No. 2 (2013) 
attempts to explain the material production that is facilitated by private property. He argues that proletarians have been used as a commodity in order to increase the capital of the bourgeoisie ${ }^{23}$. In this way by using laborers as commodities, the bourgeoisie has divided labor, where the proletarians are working for the bourgeoisie as Marx puts it, "they are daily and hourly enslaved by the machine, by the overlooked, and above all, by the individual bourgeoisie manufacturer himself" 24 . The division of labour has different effects on the workers, but the essence of private property is impeding individuals to be free as they would be in other circumstances. Marx uses present situations to demonstrate why the abolition of private property would free the majority. According to Marx "the increase in value of the world of things is directly proportional to the decrease in value of the human world" 25 . The main differentiation of this statement to that of Hegel is that Marx sees the realization of individuals after the means of production have changed, whereas Hegel offers an interpretation of how social institutions treat individuals as free agents. For Marx, different forms of alienation attempt to provide an evaluation of the effects of private property, which need to be changed in order to achieve freedom. The first alienation that the laborer undergoes is from the product. As a worker produces an object he is been alienated from it, since the product is not of his belonging. The value of the product becomes alien, after he has constructed it with effort, because it will not in any way make the worker free. Conversely, it makes him subjugated to labor, given that he needs to survive and therefore to work in order to sustain himself. Marx claims, "the more the worker exerts himself, the more powerful becomes the alien objective world which fashions against himself, the poorer he and his inner world become, the less there is that belongs to him" ${ }^{26}$. The externalization of the object does not allow for the individual to demonstrate freedom as Hegel claims, but quite contrary, the life that should belong to the worker as he elaborates on the object "belongs... to the object" 27 . The second form of alienation is by the activity of production. Since the laborer is alienated from the product he elaborates, he is also alien from the process of the production. The results of the laborer production are for the bourgeoisie; in this sense Hegel's account for the externalization of free will is only applied to the minority bourgeoisie as long as the majority of laborers work for the enrichment of this minority. The activity of production maintains laborers attached to it since they need to physically be able to survive and provide for their needs; as Marx claims, "the worker does not affirm himself in this work but denies himself, feels miserable and unhappy, develops no free physical and mental energy but mortifies his flesh and ruins his mind"28. This suggests that whereas Hegel claims that free will is attained through the different stages of property, the externalization of the object in Marx's analysis does not apply to the worker since he will not use what he produces. It is by this denial of usage that freedom of the worker is been neglected. In Marx's evaluation, freedom from the oppressive labor is required in order for individuals to exercise their freedom; and this would only happen if this process of production were modified. Marx argues that through the denial of freedom, humans are been reduced to only

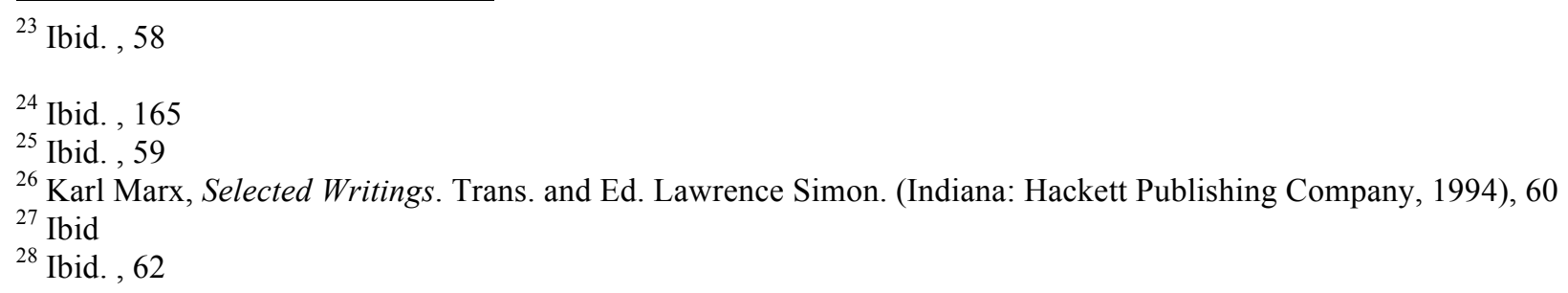

The Agora: Political Science Undergraduate Journal Vol. 3 No. 2 (2013) 
satisfying their basic needs such as eating ${ }^{29}$. The third mode of alienation is of species being. According to Marx, man considers himself as "universal and consequently free being" "30. This view in a sense is similar to that of Hegel; in the way in which freedom is supposed to be the very nature of man. The conditions in which Marx views this matter however, is through the experiences that laborers i.e. proletarians go through. Marx purpose is to change social institutions that impede the realization of freedom, a view that is directly opposed to that of Hegel. As Marx puts it, "for labor, life activity, and productive life appear to man at first only as means to satisfy a need, the need to maintain physical existence. Productive life, however, is species-life" ${ }^{31}$. In capitalism laborers are obligated to see life as a means to survival. However faculties of human beings involve also the pursuit of knowledge, the study of the natural science, or arts, which "form in practice a part of human life and human activity" 32 . Under the bourgeoisie, human faculties are in turn neglected, and man is reduced to only fulfill his basic needs like an animal ${ }^{33}$. As a result a fourth form of alienation is manifested in the relations of man to man. The mentality of laborers is based on the process of production since they dedicate their lives to the objects they produce. Marx claims, "Thus in the relation of alienated labor every man sees the others according to the standard and the relation in which he finds himself as a worker" 34 . It is through the violation of human nature that man is negatively affected to the point that he cannot develop his humanistic faculties.

The effects of these alienations make a relation between the worker and labor that Marx identifies as capitalism, "Private property is thus the product, result, and necessary consequence of externalized labor, of the external relation of the worker to nature and to himself" 35 . The externalizations of objects do not enforce the freedom of individuals, as is the case with Hegel. The reason, as Marx explains, is given to the inequality with which laborers produce. Marx offers an alternative to this situation by arguing that the abolition of private property is the solution. The problem with which Marx deals is that of the antagonism of people and nature, in how it alienates individuals from the faculties that belong to them. With the abolition of private property humanity would stop being alienated, and as it develops it would stop the construction of new needs as have been the case with the bourgeoisie. Marx claims, "Communism as positive overcoming of private property as human self-alienation, and thus as the actual appropriation of the human essence through and for man; therefore as the complete and conscious restoration of man to himself within the total wealth of previous development, the restoration of man as a social, that is, human being"36. Marx makes his point known by noting that contemporary institutions are violating the freedom and humanistic side of laborers, who conform the majority of people, nevertheless he attempts to change this by abolishing what is causing the violation. In contrast Hegel attempts to defend an ideal of the development of free will in peoples' consciousness since he does not deal with changes but rather interpretations.

\footnotetext{
${ }^{29}$ Ibid

${ }^{30}$ Ibid

${ }^{31}$ Ibid. , 63

32 Ibid

${ }^{33}$ Karl Marx, Selected Writings. Trans. and Ed. Lawrence Simon. (Indiana: Hackett Publishing Company, 1994), 64

${ }^{34}$ Ibid. , 65

${ }^{35}$ Ibid. , 66

${ }^{36}$ Ibid. , 71
}

The Agora: Political Science Undergraduate Journal Vol. 3 No. 2 (2013) 
This contrast between Hegel and Marx relies on the manner in which the theorists deal with the development of humans. The writings of Marx at the time were in a way directed to the followers of Hegel know as "Young Hegelians", one of the Marxist criticisms to them is that they do not deal with theory from the point it should depart i.e. history ${ }^{37}$. History as a difference deals with modes of production as Marx claims, "the production of ideas, of conceptions, of consciousness is directly interwoven with the material activity and the material relationships of men; it is the language of actual life. Conceiving, thinking, and the intellectual relationships of men appear here as the direct result of their material behavior" 38 . If the point of departure to analyze freedom in humans is to take into account material relations, the view of Hegel loses its validity. As a difference Hegel first acknowledges the importance of the realization of the free will in consciousness in order to be able to operate with morality and ultimately ethical life. Morality and Ethical life are themes that are discussed later, in this way prioritizing the concept of free will as departure. Hegel states that "What and how much I possess is therefore purely contingent as far as right is concerned" $(\S 49)^{39}$. Hegel rejects the possibility of equity or at least of some privilege over private property, as it is said that "the demand sometimes made for an equal division of land, and other available resources too, is an intellectualism all the more empty and superficial in that at the heart of particular differences there lies not only the external contingency of nature but also the whole compass of spirit, endlessly particularized and differentiated, and its rationality developed into an organism" 40 . Thus it is clear that for Hegel the consciousness of free will entails engagement with the external world, to the point where personality could only be recognized as different by appropriating private property. Equal distribution of production for Hegel would not be enough to make people realize of their free will since they would be limited to receive what a given regime would provide. This in turn would limit humans to conform with the given, and they would not be able to externalize their personality and free will. Although in ethical life Hegel mentions that the state should manage this matter for people whom few resources he does not explicitly offer a resolution to the problem of inequality ${ }^{41}$. It is through these conceptualizations that one can realize the fundamental differentiation of both theorists. Hegel does not attempt to change the modern world, since that is allowing for the reasoning of what it means to be free. However for Marx the development of freedom is been restricted in the majority of people, this is as a cause, affecting humanistic faculties since they cannot run their normal path.

In conclusion it is clearly seen that Hegel and Marx evaluate the modern world from very different points of view. Although both theorists acknowledge freedom as an important characteristic of humans, they elaborate on this idea in a rather opposite way. Ownership according to Hegel makes an agent self-conscious about his free will as he acquires, uses, and alienates his property. In the state freedom in his view is violated through crime or the negation of the right of freedom, and is also regulated through punishment. This realizes a person as a free

\footnotetext{
${ }^{37}$ Ibid 102

${ }^{38}$ Karl Marx, Selected Writings. Trans. and Ed. Lawrence Simon. (Indiana: Hackett Publishing Company, 1994), 111

${ }^{39}$ G.F.W Hegel, Outlines of the Philosophy of Right. Trans. T. M. Knox. Ed. Stephen Houlgate. (New York: Oxford University Press, 2008), 63-64

${ }^{40}$ Dudley Knowles, Routledge Philosophy Guidebook to Hegel and the Philosophy of Right. (New York: Routledge, 2002), 124-125

${ }^{41}$ Ibid. , 126-127
}

The Agora: Political Science Undergraduate Journal Vol. 3 No. 2 (2013) 
agent. However Hegel's theory can be questioned as to how he deals with the problem of inequality. The majority of people, who Marx talks about, would not be able to fulfill as persons since they do not own private property. In turn, Marx offers a rather different explanation as to why people cannot be free and realize as humans. His view has to do with how material production is managed in a society. According to him the change in the means of social production are needed in order for people to develop their humanistic nature. Private property in this sense is the mere impediment in allowing people freedom, given that the minority bourgeoisie own the social means of production. This results in the laborers alienation. The communistic solution to the problem of alienation is the abolition of the bourgeoisie private property, and the distribution of property in order to foster individuality and freedom. The fundamental difference of both theorists can be summed in a statement of Marx's that directly applies to Hegel; "The philosophers have only interpreted the world in various ways; the point is, to change it" $"$.

${ }^{42}$ Karl Marx, Selected Writings. Trans. and Ed. Lawrence Simon. (Indiana: Hackett Publishing Company, 1994), 101 


\section{Bibliography:}

Hegel, G.F.W. Outlines of the Philosophy of Right. Trans. T. M. Knox. Ed. Stephen Houlgate. New York: Oxford University Press, 2008.

Knowles, Dudley. Routledge Philosophy Guidebook to Hegel and the Philosophy of Right. New York: Routledge, 2002.

Marx, Karl. Selected Writings. Trans. and Ed. Lawrence Simon. Indiana: Hackett Publishing Company, 1994. 